\title{
Production of vegetable oil blends and structured lipids and their effect on wound healing
}

\author{
Juliana Neves Rodrigues Ract ${ }^{1, *}$, Fabiana Andreia Schäfer De Martini Soares ${ }^{1}$, Hosana Gomes \\ Rodrigues $^{2}$, José Ricardo Bortolon ${ }^{3}$, Gilson Masahiro Murata ${ }^{4}$, Maria Inês Almeida Gonçalves ${ }^{5}$, \\ Elaine Hatanaka ${ }^{3}$, Rui Curi ${ }^{4}$, Luiz Antonio Gioielli ${ }^{1}$
}

${ }^{1}$ Department of Biochemical and Pharmaceutical Technology, Faculty of Pharmaceutical Sciences, University of São Paulo, São Paulo, SP, Brasil, ${ }^{2}$ Laboratory of Biotechnology, Faculty of Applied Sciences, State University of Campinas, Campinas, SP, Brasil, ${ }^{3}$ Institute of Physical Activity Sciences and Sports, University Cruzeiro do Sul, São Paulo, SP, Brasil, ${ }^{4}$ Department of Physiology and Biophysics, Institute of Biomedical Sciences, University of São Paulo, São Paulo, SP, Brasil, ${ }^{5}$ Department of Pharmacy, Faculty of Pharmaceutical Sciences, University of São Paulo, São Paulo, SP, Brasil

\begin{abstract}
Two oil blends (sunflower/canola oils 85/15 (BL1) and canola/linseed oils 70/30 (BL2)), were prepared and enzymatically interesterified to be applied to surgically-induced wounds in rats. Following surgery, the animals were submitted to the Treatment with Physiological Saline (TPS) (control group), Blends (TBL), and Structured Lipids (TSL). The control group (TPS) received physiological saline solution for 15 days. In TBL, BL1 was administered during the inflammation phase (days 0-3) and BL2 in the tissue formation and remodeling phase (days 4-15). In TSL, Structured Lipid 1 (SL1) and Structured Lipid 2 (SL2) were used instead of BL1 and BL2, respectively. The aim of this study was to compare wound closure evolution among rats treated with the blends or structured lipids versus control rats treated with physiological saline. The wound healing process was evaluated by measuring the wound areas along the treatments and the concentrations of cytokines. An increase in the areas of wounds treated with the blends and structured lipids in the inflammatory phase was observed, followed by a steeper closure curve compared to wounds treated with physiological saline. The changes observed during the inflammatory phase suggest a potential therapeutic application in cutaneous wound healing which should be further investigated.
\end{abstract}

Uniterms: Structured lipid/effect/wound healing. Vegetable oil/effect/wound healing. Healing. Cutaneous wound healing/treatment.

Duas misturas de óleos vegetais (girassol/canola 85/15 (BL1) e canola/linhaça, 70/30 (BL2) foram preparadas e interesterificadas por via enzimática para serem aplicadas em feridas induzidas cirurgicamente em ratos. Após a cirurgia, os animais foram submetidos ao tratamento com soro fisiológico (TPS) (grupo controle), tratamento com as misturas (TBL) e tratamento com os lipídios estruturados (TSL). O grupo controle (TPS) recebeu soro fisiológico por 15 dias. Em TBL, BL1 foi administrada durante a fase de inflamação (dias 0-3) e BL2 na fase de formação de tecido e remodelação (dias 4-15). Em TSL, os lipídios estruturados SL1 e SL2 foram usados em vez de BL1 e BL2, respectivamente. O objetivo deste estudo foi avaliar a evolução do fechamento das feridas dos grupos de ratos tratados com as misturas ou lipídios estruturados em comparação com os ratos do grupo controle, tratados com soro fisiológico. O processo de cicatrização das feridas foi avaliado através da medição das áreas das feridas ao longo dos tratamentos e pela determinação das concentrações de citocinas. Observou-se aumento das áreas das feridas tratadas com as misturas e os lipídios estruturados na fase inflamatória, seguida por um fechamento acentuado de feridas comparado com o tratamento com solução salina. As mudanças observadas durante a fase inflamatória sugerem uma potencial aplicação terapêutica na cicatrização de feridas cutâneas, fazendo-se necessárias investigações posteriores.

Unitermos: Lipídio estruturado/efeito/cicatrização de feridas. Óleo vegetal/efeito/cicatrização de feridas. Cicatrização. Feridas cutâneas/cicatrização/tratamento.

\footnotetext{
*Correspondence: J. N. R. Ract. Departmento de Tecnologia BioquímicoFarmacêutica. Faculdade de Ciências Farmacêuticas - USP. Av. Prof. Lineu Prestes, n. 580 - Bloco 16 - 05508-900 - São Paulo - SP, Brazil. E-mail: julianaract@usp.br
} 


\section{LISTA DE ABREVIATURAS}

\author{
PUFA - Polyunsaturated fatty acid \\ FA - Fatty Acid \\ TAG - Triacylglycerol \\ BL - Blend \\ SL - Structured lipids \\ TPS - Treatment with physiological saline \\ TBL - Treatment with blend \\ TSL - Treatment with structured lipid \\ SO - Sunflower oil \\ $\mathrm{CO}$ - Canola oil \\ LO - Linseed oil \\ $\mathrm{P}$ - Palmitic acid (C16:0) \\ St - Stearic acid (C18:0) \\ O - Oleic acid (C18:1) \\ L - Linoleic acid (C18:2) \\ Ln - Linolenic acid (C18:3) \\ VEGF - Vascular endothelial growth factor \\ IL - Interleukin
}

\section{INTRODUCTION}

Burns, chronic wounds and ulcers are health problems that negatively affect the lives of millions of people worldwide, rendering wounds one of the leading concerns in modern health care (Sen et al., 2009). In wound care, the aim is to minimize the treatment period, pain, discomfort and scarring (Nevin, Rajamohan, 2010). Wound healing is a highly complex biological repair process initiated in response to injury. This process occurs in at least three overlapping stages, starting with inflammation, followed by new tissue formation and tissue remodeling, finally resulting in restoration of tissue integrity. Cytokines have multiple functions during the phases of wound repair, integrating inflammatory events and reparative processes as essential modulators of human-skin wound healing (Gillitzer, Goebeler, 2001).

Several investigators have focused efforts on demonstrating the benefits of topical wound treatment with oils, owing to their wide use by populations in many countries. Oily damp dressings offer a natural barrier against microorganisms, preventing tissue dehydration and reducing trauma when dressings are changed. The effects of fatty acids on immune cell functions have been demonstrated and reinforce the important immunomodulatory nature of these lipids (Rodrigues et al., 2011; Cardoso et al., 2004).

The literature attributes anti-inflammatory effects to n-3 and n-9 fatty acids, including $\alpha$-linolenic (18:3 $\alpha)$ and oleic (18:1) acids, and highlights the pro-inflammatory properties of fatty acids belonging to the $n-6$ series, namely linoleic acid. Previous studies by Cardoso et al. (2004) and Pereira et al. (2008) indicated acceleration in the wound healing process in rats treated with n- 6 fatty acids, as well as a tendency toward faster wound closure in rats receiving n-9 fatty acids. A tendency for delayed wound closure in rats treated with n-3 fatty acids was also observed. The modulating effects exerted by fatty acids was indicated by marked changes in the wounds during the inflammation period of the healing process, attributed to the effects of fatty acids on neutrophil migration and cytokine production in the injured area.

Vegetable oils are the main source of unsaturated fatty acids (PUFAs) and their utilization as a raw material for the production of a large number of nutraceutical and pharmaceutical products of high added value occurs owing to their low cost. In the most conclusive studies regarding the regulating effect of omega-3 (n-3), omega-6 (n-6), and omega-9 (n-9) fatty acids on immune cell functions, these fatty acids have been either topically administered or supplemented in their free form and at a very high degree of purity (Pereira et al., 2008; Rodrigues et al., 2010). Other groups have used blends of these fatty acids or edible vegetable or animal oils (Nevin,Rajamohan, 2010; McDaniel et al., 2008; Otranto, Nascimento, Monte-AltoCosta, 2010).

Nevertheless, most natural fats and oils have limited industrial application due to their fatty acid and triacylglycerol compositions. In order to broaden their application, natural fats and oils are often modified by methods such as blending and interesterification, resulting in products with the desired physicochemical or functional properties by rearranging the fatty acids in the triacylglycerol molecules using interesterification processes (Chiu, Gioielli, Grimaldi, 2008; Reena, Lokesh, 2007). Structured lipids are defined as triacylglycerols that have been restructured to change their fatty acid composition and/or positional distribution in glycerol molecules (Lee, Akoh, 1998). Lipases can be used as catalysts with positional specificity toward ester bonds in sn-1,3 positions of the triacylglycerol (Willis, Marangoni, 2008).

There is evidence that not only the fatty acid composition of lipids, but also the intramolecular position of fatty acids in the triacylglycerol molecules, have a strong influence on the way they are metabolized in the digestive system and the resulting nutritional effects (Mu, Porsgaard, 2005). Most studies on lipids for health and nutrition have focused on their fatty acid composition. However, the distribution of these fatty acids in the triacylglycerol molecule is specific for the native 
fats and oils. The fat randomization resulting from the interesterification process leads to the formation of new triacylglycerol molecular species.

Aiming to compare the effects of structured lipids and their original vegetable oil blends on wound healing evolution in rats, two different vegetable oil blends were prepared and then interesterified via enzymatic catalysis to synthesize structured lipids. These lipid sources, presenting the same fatty acid composition but different fatty acid regiospecific distribution among TAG positions, were applied in surgically induced wounds on the dorsal surface of rats following different protocols, described further on.

\section{MATERIAL AND METHODS}

\section{Material}

Refined, bleached, and deodorized sunflower and canola oils (Bunge, Brazil) were acquired from a local grocery store (São Paulo, Brazil). Linseed oil was obtained from the manufacturer Vital Âtman (Uchoa, Brazil). Commercial immobilized lipase from Thermomyces lanuginosus (Lipozyme TL IM) was purchased from LNF Latino Americana (Bento Gonçalves, Brazil). The enzyme activity of the lipase was $250 \mathrm{IUN} / \mathrm{g}$. All other reagents and solvents were of analytical or chromatographic grade.

\section{Animals}

Male Wistar rats weighing 160-200 g from the Department of Physiology and Biophysics, Institute of Biomedical Sciences, University of São Paulo (São Paulo, Brazil) were used in the present study. The animals were housed in cages (maximum of five per cage) maintained at $23{ }^{\circ} \mathrm{C}$ under a lighting regimen of $12 / 12 \mathrm{~h}$. Food and water were given ad libitum (Pereira et al., 2008). All experiments were conducted according to the guidelines of the Animal Care Committees of the Institute of Biomedical Sciences and the Faculty of Pharmaceutical Sciences of the University of São Paulo (Protocol Numbers CEEA ICB/ USP 68-71-2 and CEEA FCF/USP 236).

\section{Blend preparation}

Two binary oil blends were prepared, namely BL1 and BL2, composed of sunflower and canola oils at 85/15 (w/w) and canola and linseed oils at 70/30 (w/w) proportions, respectively. These proportions were established with the aim of obtaining an approximate ratio between oleic and linoleic fatty acids of 1:2 in BL1 and a ratio of 2.5:1:1 between oleic, linoleic, and $\alpha$-linolenic acids in BL2. The blends were prepared at $40{ }^{\circ} \mathrm{C}$ for $30 \mathrm{~min}$ under stirring in a screw agitator (Ika RW20.n, Germany) and then stored at $-18^{\circ} \mathrm{C}$.

The proportions of fatty acids in the blends were defined based on a vast body of literature (outlined previously) that attributes anti-inflammatory effects to the n-3 fatty acids, including $\alpha$-linolenic acid (18:3 $\alpha)$, and highlights the pro-inflammatory properties of fatty acids belonging to ne $n-6$ series, namely linoleic acid. The incorporation of n-9 oleic acid into the blends, besides contributing to faster wound closure, can prevent lipid peroxidation of structured lipids potentially initiated during enzymatic interesterification due to their exposure to favorable conditions.

\section{Enzymatic interesterification reaction}

The enzymatic interesterification was carried out on a continuous packed bed bioreactor built with a jacketed glass column ( $34 \mathrm{~cm} \times 2 \mathrm{~cm}$ i.d.) packed with $70 \mathrm{~g}$ of Lipozyme TL IM where the upper and lower ends of the column were layered with glass wool to support the enzyme. The column temperature was constantly maintained at $60^{\circ} \mathrm{C}$ by a circulating water bath (RE 112 , Lauda, Germany) and the substrate mixtures, kept under smooth magnetic stirring at $75^{\circ} \mathrm{C}$ in a vessel, were fed upward through the column using a peristaltic pump (VC 360II, Ismatec, Switzerland). The flow rate was kept at $1 \mathrm{~mL} / \mathrm{min}$, resulting in a residence time of 1 hour of the substrate in the reactor. For lipase conditioning, sunflower oil was initially introduced into the reactor at a flow rate of $1 \mathrm{~mL} / \mathrm{min}$ to remove air and water from the enzyme until the free fatty acids of the interesterified oil presented a stable value $(<0.7 \mathrm{~g}$ oleic acid/100 $\mathrm{g}$ oil $)$. After conditioning of the enzyme, the blends were pumped into the reactor under the same conditions. Each different interesterified sample was collected $(200 \mathrm{~mL})$ after discarding the first $200 \mathrm{~mL}$ to avoid cross-contamination with the previous blend, and stored at $-18^{\circ} \mathrm{C}$. After the reaction, enzymatically interesterified BL1 and BL2 were designated SL1 and SL2 (Structured Lipids 1 and $2)$, respectively.

\section{Fatty acid composition}

Fatty acid composition was determined on a Varian GC gas chromatograph (430 GC, Varian Chromatograph Systems, USA), equipped with a CP 8412 auto injector. The Galaxie software package was used for quantification and identification of peaks. Injections were performed 
on a $100 \mathrm{~m}$ fused silica capillary column $(\mathrm{ID}=0.25 \mathrm{~mm}$ ) coated with $0.2 \mu \mathrm{m}$ of polyethylene glycol (SP-2560, Supelco, USA) using helium as the carrier gas at an isobaric pressure of $37 \mathrm{psi}$; linear velocity of $20 \mathrm{~cm} / \mathrm{s}$; makeup gas: helium at $29 \mathrm{~mL} / \mathrm{min}$ at a split ratio of 1:50; volume injected: $1.0 \mu \mathrm{L}$. The injector temperature was set at $250{ }^{\circ} \mathrm{C}$ and the detector temperature at $280{ }^{\circ} \mathrm{C}$. The oven temperature was initially held at $140{ }^{\circ} \mathrm{C}$ for 5 min, programmed to increase to $240{ }^{\circ} \mathrm{C}$ at a rate of $4{ }^{\circ} \mathrm{C} /$ $\mathrm{min}$, and then held isothermally for $30 \mathrm{~min}$ (Soares et al., 2009). Fatty acids in the triacylglycerols of the blends and structured lipids were converted into fatty acid methyl esters (FAME) by saponification with $0.5 \mathrm{~mol}$ equiv/L methanolic potassium hydroxide, followed by refluxing with a solution of ammonium chloride and sulphuric acid in methanol according to the methodology proposed by Hartman and Lago (1973). Qualitative FA composition of the samples was determined by comparing the retention times of the peaks with those of the respective standards of the fatty acids. Quantitative composition was accomplished by area normalization, expressed as mass percent, according to the Ce 1-62 method (AOCS, 2004). Samples were run in triplicate and values were averaged.

\section{Triacylglycerol composition}

Triacylglycerol composition was determined by a Varian capillary gas chromatography system, model 3400CX (Varian, Brazil). A DB-17HT capillary column (50\% phenylmethylpolysiloxane, $15 \mathrm{~m}$ length $\mathrm{x} 0.25 \mathrm{~mm}$ internal diameter and $0.15 \mu \mathrm{m}$-thick film) from Agilent (Santa Clara, USA) was used. Flow rate was $1.0 \mathrm{~mL} / \mathrm{min}$ with an injector temperature of $360^{\circ} \mathrm{C}$, detector temperature of $375{ }^{\circ} \mathrm{C}$, oven temperature from $250{ }^{\circ} \mathrm{C}$ programmed up to $350{ }^{\circ} \mathrm{C}$ at $5{ }^{\circ} \mathrm{C} / \mathrm{min}$. The volume injected was $1.0 \mu \mathrm{L}$ with 1:30 split, sample concentration was $1 \mathrm{mg} / \mathrm{mL}$ of $\mathrm{n}$-hexane, and helium was used as the carrier gas. Identification of the triacylglycerol groups was performed by comparing retention times, according to Antoniosi-Filho et al. (1995).

\section{Regiospecific distribution of fatty acids}

The regiospecific distribution of fatty acids on the triacylglycerol backbones was determined by protondecoupled ${ }^{13} \mathrm{C}$-NMR (Vlahov, 2008; Wang et al., 2010; Standal et al., 2009). Lipid samples of $250 \mathrm{mg}$ were dissolved in $0.5 \mathrm{~mL}$ of deuterated chloroform $\left(\mathrm{CDCL}_{3}\right)$ using 5-mm NMR tubes. NMR spectra were recorded on a Bruker Avance DPX spectrometer operating at $300 \mathrm{MHz}$. The ${ }^{13} \mathrm{C}$ spectra were acquired with a spectral width of
2,332.090 Hz, pulse of $10.2 \mu$ s, and relaxation delay of $30 \mathrm{~s}$. Determination of ${ }^{13} \mathrm{C}$ was performed at a frequency of $75.8 \mathrm{MHz}$ with a $5 \mathrm{~mm}$ multinuclear probe operating at $30{ }^{\circ} \mathrm{C}$. The results showed the compositions of saturated fatty acids, oleic acid and linoleic + linolenic acids in sn-2 and $s n-1,3$ positions.

\section{Thermal behavior}

The thermal behavior curves were obtained using a differential scanning calorimetry (DSC) cell on the DSC 4,000 Perkin Elmer (Perkin Elmer Corp., Norwalk, CT, USA), under a dynamic atmosphere of $\mathrm{He}(20 \mathrm{~mL} / \mathrm{min})$, using sealed aluminum capsules, each containing a sample mass of 5-10 mg. The samples were initially kept at $80{ }^{\circ} \mathrm{C}$ for $10 \mathrm{~min}$, then cooled at $-10{ }^{\circ} \mathrm{C} / \mathrm{min}$ up to $-60{ }^{\circ} \mathrm{C}$, following an isothermal time of $10 \mathrm{~min}$, and finally heated to $80^{\circ} \mathrm{C}$ at $5{ }^{\circ} \mathrm{C} / \mathrm{min}$. The temperature and heat of melting and fusion were calibrated with indium (initial temperature $156.6^{\circ} \mathrm{C}$ ). Curves were processed by the Pyris software, and crystallization curves analyzed for the onset of crystallization $\left(\mathrm{T}_{\text {onset }}{ }^{\circ} \mathrm{C}\right)$, peak crystallization temperatures $\left(\mathrm{T}_{\text {peak }}{ }^{\circ} \mathrm{C}\right)$ and crystallization enthalpies $\left(\Delta \mathrm{H}_{\mathrm{c}} \mathrm{J} / \mathrm{g}\right)($ Silva et al., 2013).

\section{Wound induction}

Animals were anesthetized with an intraperitoneal injection of $0.4 \mu \mathrm{g} / \mathrm{g}$ xylazine and $18 \mu \mathrm{g} / \mathrm{g}$ ketamine (Virbac, São Paulo, Brazil) and the skin on the dorsal flank was shaved. After rinsing the shaved surface with ethanol at $70 \%$, an excision wound was made by cutting out a $1.0 \mathrm{~cm} \times 1.0 \mathrm{~cm}$ piece of skin from the shaved area. The wounds were of the full-thickness type extending down to the subcutaneous tissue (Pereira et al., 2008).

\section{Treatments}

Following surgery, the animals were immediately treated according to the TPS (control group), TBL, and TSL protocols. The control group (TPS) received a commercial sterile physiological saline solution for 15 days. TSL consisted of administering BL1 during the 3 -day period corresponding to the inflammation phase and then BL2 from the third day until the end of the treatment, corresponding to tissue formation and tissue remodeling phases (Park,Barbul, 2004). TSL was similar to TBL, but SL1 and SL2 were used instead of BL1 and BL2, respectively. The wounds received daily topical applications of $200 \mu \mathrm{L}$ each for a total period of 15 days. The volume used fully covered the wound healing area. 
This protocol was established based on the protocols used by Cardoso et al. (2004) and Pereira et al. (2008).

\section{Macroscopic analysis}

To investigate the in vivo effect of the treatments on the wound healing process, a macroscopic analysis was performed using six animals for each treatment $(n=6)$. The wound was prepared in sterile conditions. The granite workbench was cleaned with hypochlorite plus alcohol. All the surgical material was autoclaved before surgery and after each wound it was cleaned with alcohol.

The wound area was measured immediately after surgery and then again at 1, 2, 3, 5, 7, 10, and 15 days after tissue removal. The wounds were photographed using a digital camera (EOS Rebel XS, Canon) equipped with a macro objective lens (EF-S $60 \mathrm{~mm}$ f/2.8 Macro USM, Canon), and flash lights (MR-14EX Macro Ring Lite, Canon). The wounds in the images were manually contoured and the areas measured using Image Pro Plus Software (Media Cybernetics). Wound closure was calculated according to Equation 1, where X corresponds to the number of days after the surgery. Negative results represent increase in wound area.

\section{$\%$ Wound Closure $=\frac{(\text { Area at } t=0)-(\text { Area at } t=X)}{\text { Area at } t=0} \times 100$ \\ Determination of cytokine concentrations in wound tissue}

(Eq. 1)

Wound lesion tissues removed after induction were immediately packed in dry ice and kept frozen $\left(-80^{\circ} \mathrm{C}\right)$ until they were homogenized. For homogenization, phosphate-buffered saline was supplemented with protease inhibitors ( $0.5 \mathrm{~m} \mathrm{PMSF}$ and $25 \mathrm{IU} \mathrm{mL}^{-1}$ aprotinin). Tissue (100 mg) was homogenized with Polytron PT 3100 (Kinematica, Lucerne, Switzerland). Samples were next sonicated for 1 minute and centrifuged at $1,000 \times g$ and $4{ }^{\circ} \mathrm{C}$ for 10 minutes. The concentrations of cytokines
(L-Selectin, IL-6, and VEGF-a) in the supernatants were assessed by ELISA using the Duo Set kit (R\&D System) immediately after surgery and after 2, 5, and 7 days of treatment. The concentrations were normalized by the amount of protein in the samples, determined by the method described by Bradford (1976).

\section{Statistical analysis}

Statistical analysis was carried out by comparing the control group (TPS) with the groups treated with the blends (TBL) and the respective structured lipids (TSL). Statistical software, version 10.0 (StatSoft, USA) was used to perform one-way ANOVA followed by post hoc Tukey tests to identify statistical differences between the treatments. Results were considered significant when $\mathrm{p}<0.05$.

\section{RESULTS AND DISCUSSION}

\section{Fatty acid composition}

Fatty acid compositions of canola oil, sunflower oil, linseed oil, their blends, and respective structured lipids are given in Table I. The determined values for sunflower and canola oils fatty acid compositions were within the official limits listed in the Codex Alimentarius Standards for Named Vegetable Oils (CODEX, 2011). Among the most commercially available oils, sunflower oil is one of the richest in linoleic acid, with this fatty acid representing $61.0 \mathrm{~g} / 100 \mathrm{~g}$ of the sunflower oil used in this study. This oil was therefore chosen to be the source of n- 6 fatty acids in BL1. Canola oil is composed of $64.9 \mathrm{~g} / 100 \mathrm{~g}$ of oleic acid and was blended with sunflower oil, as a source of n-9 fatty acids, to produce BL1, a blend with an oleic acid: linoleic acid ratio of $1: 2$. Linseed oil contained $51.0 \mathrm{~g} / 100 \mathrm{~g}$ of $\alpha$-linolenic acid and its composition was in accordance with other reports describing its high $\alpha$-linolenic content as its main characteristic (White, 2008; Gunstone, Harwood, 2007). Linseed oil was blended with canola oil

TABLE I - Fatty acid composition (g/100 g) of canola oil (CO), sunflower oil (SO), linseed oil (LO) and of blends before (BL1 and BL2) and after (SL1 and SL2) continuous enzymatic interesterification

\begin{tabular}{lccccccc}
\hline Fatty acid & CO & SO & LO & BL1 & SL1 & BL2 & SL2 \\
\hline C16:0 (P) & $4.7 \pm 0.0$ & $6.5 \pm 0.1$ & $6.3 \pm 0.1$ & $6.3 \pm 0.1$ & $5.9 \pm 0.0$ & $5.4 \pm 0.1$ & $5.1 \pm 0.0$ \\
C18:0 (St) & $2.4 \pm 0.0$ & $3.4 \pm 0.0$ & $5.4 \pm 0.0$ & $3.2 \pm 0.0$ & $3.2 \pm 0.0$ & $3.5 \pm 0.0$ & $3.4 \pm 0.0$ \\
C18:1 (O) & $64.9 \pm 0.0$ & $28.7 \pm 0.0$ & $22.5 \pm 0.0$ & $34.1 \pm 0.1$ & $34.1 \pm 0.0$ & $50.1 \pm 0.1$ & $50.8 \pm 0.0$ \\
C18:2(L) & $20.3 \pm 0.0$ & $61.0 \pm 0.1$ & $14.8 \pm 0.0$ & $54.9 \pm 0.1$ & $55.5 \pm 0.0$ & $18.4 \pm 0.0$ & $18.1 \pm 0.0$ \\
C18:3 $(\mathrm{Ln})$ & $7.7 \pm 0.0$ & $0.4 \pm 0.0$ & $51.0 \pm 0.0$ & $1.5 \pm 0.1$ & $1.3 \pm 0.0$ & $22.6 \pm 0.0$ & $22.6 \pm 0.0$ \\
\hline
\end{tabular}

$\mathrm{P}=$ Palmitic acid; $\mathrm{St}=$ Stearic acid; $\mathrm{O}=$ Oleic acid; $\mathrm{L}=$ Linoleic acid; $\mathrm{Ln}=\alpha$-Linolenic acid 
to produce BL2, at a proportion of 2.5:1:1 (oleic: linoleic: $\alpha$-linolenic).

The fatty acid proportions of the blends were as expected and the structured lipids obtained had very similar compositions to their original blends, thus confirming the efficiency of the interesterification reaction, showing no significant degradation resulting from exposure of the lipids to heat, light and air oxygen during the process.

\section{Triacylglycerol composition}

The triacylglycerol compositions of the blends before and after enzymatic interesterification are shown in Figure 1. Gas chromatographic analysis allowed the identification of triacylglycerol groups defined by their carbon numbers and degree of unsaturation. Literature and chromatographic standards aided identification of the main triacylglycerols of the groups, with each group represented by a pair of bars in each figure.

The results clearly reveal triacylglycerol redistribution due to interesterification both when comparing BL1 to SL1 and BL2 to SL2. In Figure $1(a)$, significant differences $(\mathrm{p}<0.05)$ before and after interesterification were observed in groups 52:3, 52:4, $54: 3,54: 4,54: 5$ and 54:6, which were also the main groups comprising BL1 and SL1. Interesterification caused a decrease in the amount of triacylglycerols with 52 carbon atoms from 18.5 to $13.5 \mathrm{~g} / 100 \mathrm{~g}$. Group 52:3, composed mainly of PStLn and POL, showed an increase from 5.9 to $7.9 \mathrm{~g} / 100 \mathrm{~g}$ whereas the triacylglycerols of group 52:4, mainly represented by POLn and PLL, decreased from 8.8 to $6.4 \mathrm{~g} / 100 \mathrm{~g}$ after the interesterification reaction.

54C triacylglycerols were the most abundant group in both BL1 and SL1 and showed an increase from 80.3 to $85.7 \mathrm{~g} / 100 \mathrm{~g}$ with interesterification. While the rearrangement caused decreases of 5.7 and $4.2 \mathrm{~g} / 100 \mathrm{~g}$ in the 54:3 (StStLn/StOL/OOO) and 54:6 (StLnLn/ OLLn/LLL) groups for BL1, respectively, the groups 54:4 (StOLn/StLL/OOL) and 54:5 (StLLn/OOLn/ OLL) increased their triacylglycerols by 5.1 and 6.1 $\mathrm{g} / 100 \mathrm{~g}$, respectively. SO contained $20.6 \mathrm{~g} / 100 \mathrm{~g}$ of LLL (54:6), while OOO (54:3) was present in $20.6 \mathrm{~g} / 100 \mathrm{~g}$ of CO (Gunstone \& Harwood, 2007; Firestone, 2006). Therefore, BL1, composed of $\mathrm{SO}$ and $\mathrm{CO}$, showed a decrease in triacylglycerols formed exclusively by one type of fatty acid, namely trilinoleins and trioleins, which were replaced by triacylglycerols presenting mainly two different types of fatty acids in the same molecule. The fatty acid compositions of the blends and structured lipids contributed to the interpretation of the triacylglycerol chromatograms, leading to the assumption that SL1 contained mostly dilinoleins, as linoleic acid comprised around $55 \mathrm{~g} / 100 \mathrm{~g}$ of BL1 and SL1. In addition, it could be inferred that these dilinoleins contain mainly oleic acid, the second most abundant fatty acid in BL1 and SL1, present in $34 \mathrm{~g} / 100 \mathrm{~g}$.
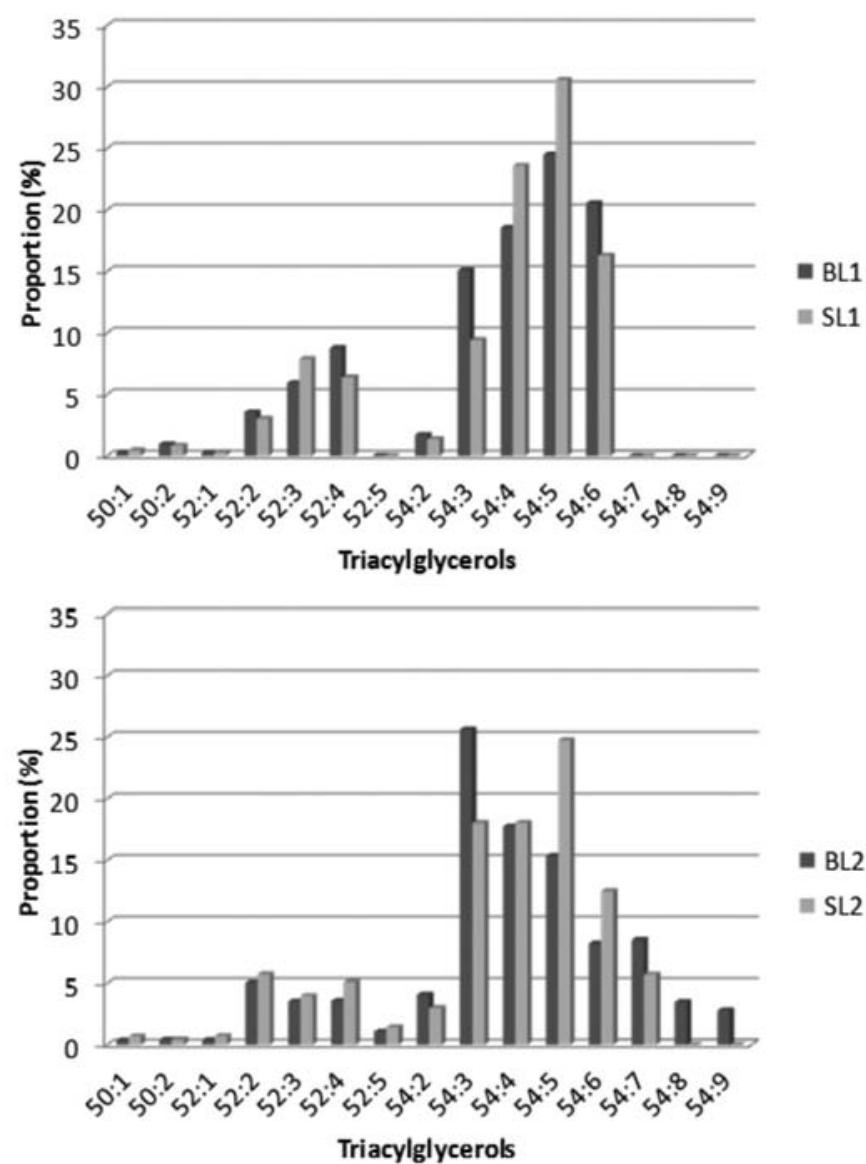

FIGURE 1 - Triacylglycerol composition of the blends before and after interesterification; (a) Blend 1 (BL1) and Structured Lipid 1 (SL1); (b) Blend 2 (BL2) and Structured Lipid 2 (SL2)

The occurrence of fatty acid redistribution in SL2 after interesterification of BL2 is shown in Figure 1(b). Except for groups 50:2 (PPL), 52:3 (PStLn/POL) and 54:4 (StOLn/StLL/OOL), all other triacylglycerol groups exhibited significant differences in these amounts $(p<0.05)$. Likewise, SL2 also had less repetition of the same type of fatty acids in the same triacylglycerol molecule. The trilinolenins (LnLnLn, 54:9) and dilinolenins LLnLn (54:8), derived mainly from linseed oil, which constituted $30 \%$ of BL2, were not present in SL2. Trioleins (OOO) and dilinolenins OLnLn, the main constituents of 54:3 and 54:7 groups, were decreased after fatty acid redistribution resulting from interesterification of BL2. Conversely, the triacylglycerol groups 54:5 and 54:6, composed mainly of OOLn, OLL and OLLn, showed an increase in their 
triacylglycerol levels. Therefore, interesterification apparently distributed fatty acids more homogeneously between the triacylglycerols, forming molecules containing two or three different types of fatty acids.

Costales-Rodríguez et al. (2009) carried out a study in which palm stearin and soybean oil blends were interesterified either chemically or enzymatically using Lipozyme TL IM for the production of structured lipids. The triacylglycerol composition of the structured lipids obtained via enzymatic reaction showed a decrease in trisaturated (SSS) and triunsaturated (UUU) triacylglycerol amounts, while an increase in triacylglycerols of SUS and SUU types occurred. The redistribution of fatty acids in this case was very similar to that observed when chemical interesterification was used. The authors attributed this similarity to a probable random redistribution of fatty acid, despite the use of an $s n-1,3$ specific lipase.

Hence, the significant differences between triacylglycerol compositions when comparing BL1 to SL1, as well as BL2 to SL2, reveal that a rearrangement of fatty acids indeed occurred as a result of interesterification.

\section{Regiospecific distribution of fatty acids}

In addition to fatty acid and triacylglycerol compositions, the regiospecific distribution of fatty acids should be considered when their effects are examined. The fatty acid distribution among the three positions of triacylglycerols is characteristic for native oils and fats. Fats and oils derived from vegetable sources contain unsaturated fatty acids in the $s n-2$ position and saturated fatty acids in the sn-1 and sn-3 positions (Hunter, 2001; Karupaiah,Sundram, 2007).

The regiospecific distribution of fatty acids at $s n-2$ and sn-1,3 positions of triacylglycerols in the blends and structured lipids is shown in Figure 2. Different letters for each material, namely BL1, SL1, BL2, and SL2, when comparing (a) and (b), indicate significant differences $(p<0.05)$. The significant differences in the distribution profile substantiate the occurrence of the fatty acids rearrangement among the positions.

In the blends, linoleic and linolenic polyunsaturated fatty acids were concentrated mostly at the $s n-2$ position, representing $68.9 \mathrm{~g} / 100 \mathrm{~g}$ of the fatty acids at this position in BL1 and $53.0 \mathrm{~g} / 100 \mathrm{~g}$ in BL2, while $49.1 \mathrm{~g} / 100 \mathrm{~g}$ of the fatty acids esterified to the $s n-1,3$ positions in BL1 and $34.7 \mathrm{~g} / 100 \mathrm{~g}$ in BL2 were linoleic + linolenic. After the interesterification reaction, these fatty acids had a largely uniform distribution, despite being statistically different, between sn-2 and sn-1,3 positions, representing $56.7 \mathrm{~g} / 100 \mathrm{~g}$ of the fatty acids at the $s n-2$ position and $55.5 \mathrm{~g} / 100 \mathrm{~g}$ of the fatty acids at the sn-1,3 positions in structured lipid SL1. The same occurred for SL2, in which $42.4 \mathrm{~g} / 100 \mathrm{~g}$ of the fatty acids at the $s n-2$ position and $40.2 \mathrm{~g} / 100 \mathrm{~g}$ at the sn-1,3 positions were linoleic + linolenic acids.

Oleic acid also exhibited a reasonably uniform distribution between sn-2 and sn-1,3 positions, albeit statistically different, in both BL1 and BL2. Nevertheless, after interesterification, oleic acid distribution was statistically equal when comparing its esterification to the $s n-2$ and sn-1,3 positions in both SL1 and SL2.

Before the enzymatic interesterification reaction, BL1 and BL2 did not present saturated fatty acids at the sn-2 position. Unexpectedly, 8.8 and $8.2 \mathrm{~g} / 100 \mathrm{~g}$ of the fatty acids occupying the sn- 2 position in the SL1 and SL2 structured lipids, respectively, were saturated, although an sn-1,3 specific lipase was used to promote the fatty acid redistribution in the blends. These values were similar to those found for the $s n-1,3$ positions $(10.2 \mathrm{~g} / 100 \mathrm{~g}$ each, coincidently) in SL1 and SL2, yet statistically different at $\mathrm{p}<0.05$.

Based on these results, it is possible to state that Lipozyme TL IM used to catalyze the interesterification reaction under the processing conditions described did not display the expected specificity and that the fatty acid redistribution resulting from this reaction was virtually random, probably due to acyl migration.

According to Gunstone and Herslöf (2000), acyl migration is defined as a process that may occur spontaneously in mono and diacylglycerols by which chemically-bonded acyl groups move to adjacent $\mathrm{OH}$ (or $\mathrm{NH}_{2}$ ) groups, leading to the creation of undesired structured triacylglycerols. Acyl migration generally involves migration from the $s n-1,3$ to $s n-2$ position when an $s n-1,3$ specific lipase is used but the opposite can also occur (Yang, Fruekilde, Xu, 2005).

The effects of processing parameters on acyl migration have been widely investigated. Temperature seems to be one of the most important factors, exerting great influence on acyl migration levels. Long reaction times, high water content and water activity can also enhance acyl migration and by-product formation, as well as lipase carriers, such as resin and silica. On the other hand, packed enzyme bed reactors have great advantages over stirred tank reactors in reducing acyl migration $(\mathrm{Xu}$, 2000a; Xu, 2000b; Yang, Xu, Li, 2001).

Kim and Akoh (2006) prepared structured lipids from roasted sesame oil and caprylic acid by Rhizomucor miehei lipase-catalyzed acidolysis on a bench-scale continuous packed bed reactor. In this study, the authors observed total incorporation of caprylic acid into triacylglycerols of sesame oil of $42.5 \mathrm{~mol} \%$ and a level of 


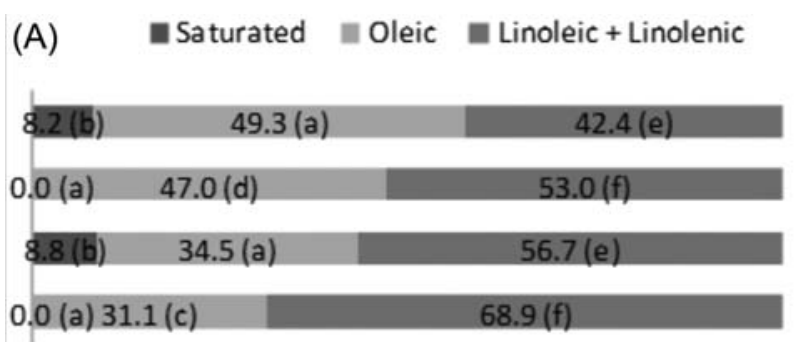

$\mathrm{SL} 2$ BL2 SL1 BL1

(B)

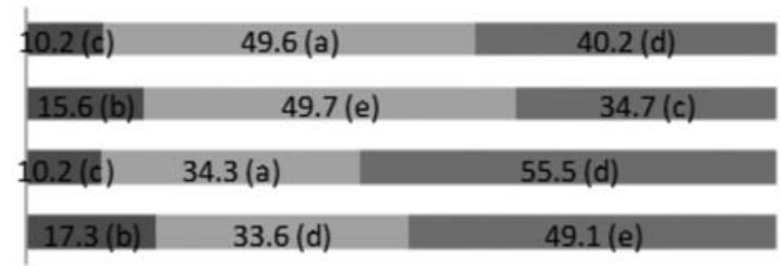

FIGURE 2 - Fatty acid regiospecific distribution of the blends (BL1 and BL2) and structured lipids (SL1 and SL2) (A) in the sn-2 position and (B) in the sn-1,3 positions of triacylglycerols. Different letters for each material, when comparing (a) and (b) mean significant differences $(\mathrm{p}<0.05)$.

acyl migration (CA found at the sn-2 position) in the SL of $3.1 \mathrm{~mol} \%$. The low level of acyl migration was attributed to lower reaction temperatures and a higher FFA/TAG (FFA=free fatty acids; $\mathrm{TAG}=$ triacylglycerols $)$ proportion compared to previous studies by the group. Nevertheless, acyl migration could not be totally avoided and the authors emphasized the difficulty in completely preventing the phenomenon.

Oh et al. (2009) synthesized structured lipids by acidolysis of olive oil and capric acid with Lipozyme TL IM using a 1:3 molar ratio of olive oil and capric acid under solvent-free reaction systems at $50{ }^{\circ} \mathrm{C}$. Capric acid incorporation into triacylglycerols of the olive oil rose as water activity increased, but the degree of acyl migration also increased. The results of these authors suggested that acyl migration can be efficiently minimized by a shorter reaction time at higher water activity.

\section{Thermal behavior}

The above-mentioned changes in the chemical composition of the blends after interesterification can also be verified by the changes in their thermal behaviors, as illustrated in Figure 3.

BL1 presented two crystallization peaks, at $-15.3^{\circ} \mathrm{C}$ and $-55.6{ }^{\circ} \mathrm{C}$, which were shifted to $-22.3{ }^{\circ} \mathrm{C}$ and $-51.0^{\circ} \mathrm{C}$ in SL1 (Figure 3(a)). These peak widths were 15.7 and $5.1{ }^{\circ} \mathrm{C}$ respectively, and increased to 33.0 and $9.9^{\circ} \mathrm{C}$ in SL1 after interesterification. Natural stereospecificity of fatty acids in the triacylglycerols of the oils constituting BL1 could be responsible for a relatively limited range of TAG types, which became more diversified after randomization of fatty acids, represented by a wider peak observed in SL1 (Hunter, 2001; Karupaiah; Sundram, 2007). The differences between BL1 and SL1 melting curves observed in Figure 3(b) corroborate the assertion that interesterification indeed occurred. Their peaks and respective peak widths present similar values, except for the peak that shifted from $8.2{ }^{\circ} \mathrm{C}$ in BL1 to $13.7^{\circ} \mathrm{C}$ in SL1.

BL2 and SL2 crystallization profiles (Figure 3(a)) illustrate the differences in their chemical compositions due to rearrangement. BL2 presented peaks at $-22.0^{\circ} \mathrm{C}$ and $-52.6{ }^{\circ} \mathrm{C}$, while in SL2 the peaks were formed at $-10.1{ }^{\circ} \mathrm{C}$ and $-46.6{ }^{\circ} \mathrm{C}$. The differences in the melting curves obtained for BL2 and SL2 are shown in Figure 3(b) and were even more evident. BL2 presented two main peaks at
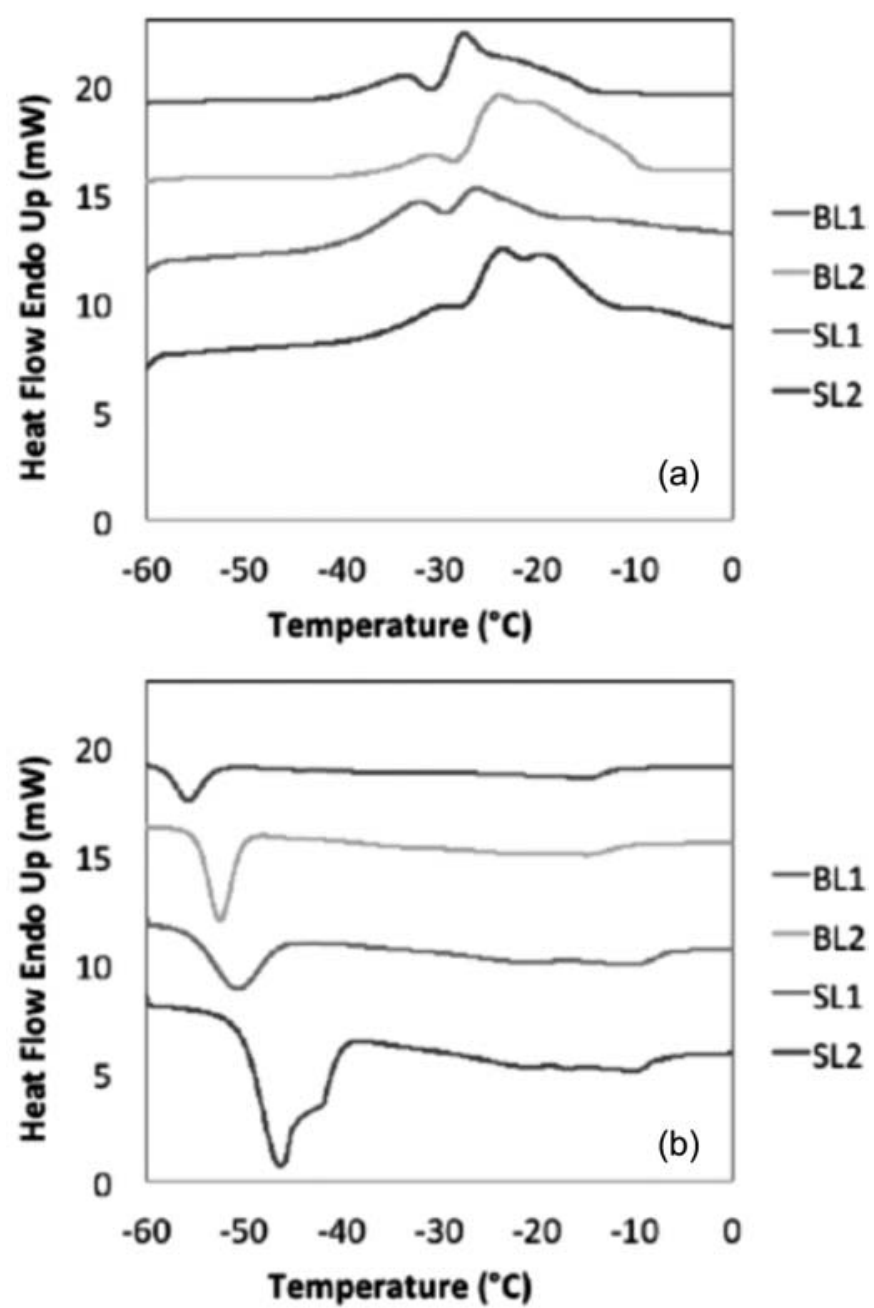

FIGURE 3 - Melting (a) and crystallization (b) behavior of blends (BL1 and BL2) and their respective structured lipids (SL1 and SL2). 
-22.0 and $-52.6^{\circ} \mathrm{C}$, while in SL2 these peaks were shifted to -10.1 and $-46.6^{\circ} \mathrm{C}$. BL2 and SL2 presented even more marked differences in their melting behaviors.

\section{Biological studies}

Our group, akin to others, has previously demonstrated the modulating effect of fatty acids on the wound healing process (Rodrigues et al., 2011; Cardoso et al., 2004; Pereira et al., 2008; Rodrigues et al., 2010; McDaniel et al., 2008). In these studies, the fatty acids were used in their free form, presenting a high level of purity, and administration was oral or topical on the wound. However, the use of esterified fatty acids in the treatment of chronic wounds has also been reported (Otranto et al., 2010). Nevertheless, no previous study has established a relationship between the regiospecific distribution of the fatty acids and the intensity of their healing properties.

In the present study, since triacylglycerol restructuring was confirmed by triacylglycerol composition analysis and fatty acid regiospecific distribution, it was decided to test the application of both the blends, and the resulting structured lipids, using a biological test to compare their performances. A macroscopic analysis of the wound healing process was performed by measuring the areas of surgically-induced wounds on the dorsal surface of rats and calculating the closure of these wounds treated according to three different protocols for 15 days.

Selected images for each proposed treatment taken on days $0,1,2,3,5,7,10$, and 15 after tissue removal are shown in Figure 4. Each column of pictures represents the wound healing evolution of a specific animal that, among all others, best illustrated the process. The images were used to measure the areas and calculate the percentage wound reduction over the 15-day treatment period with results depicted in the box and whisker plots shown in Figure 5.

An important difference between the healing process of wounds treated according to the control TPS protocol and to TBL and TSL lipid protocols was the negative values calculated for percentage wound closure for the lipids. These negative values indicate that, during a certain period of time, the wound areas expanded when treated with lipids. This was probably as a result of the pro-inflammatory properties of BL1 and SL1, used during the first few days of TBL and TSL treatments, respectively. TBL caused an increase in the wound areas from the first day of treatment, maintaining the wound size approximately constant up to the third day. TSL, in turn, apparently induced this growth in area only on the third day of treatment. In both cases, all wound areas only decreased from the fourth day onwards. This increase in wound area was not observed under treatment with physiological saline solution, which instead following the natural wound healing process.

According to the statistical analysis, no significant differences $(p<0.05)$ in wound closure were observed on the first day after surgery, or between day 05 and day 15 , when comparing TPS, TBL, and TSL. On day 02 , wounds treated with TPS closed $18.1 \%$ versus $10.0 \%$ with TSL. The TBL group showed an expansion in area of $5.0 \%$ over this period. On the third day, TPS treatment decreased the wound area by $33.0 \%$, while TBL and TSL increased it by $5.9 \%$ and $4.5 \%$, respectively.

Contrary to the evolution in the first three days, from the fifth to the fifteenth day, the wounds treated

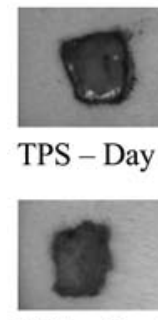

TPS - Day 01

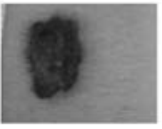

TPS - Day 02

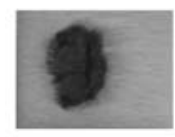

TPS - Day 03

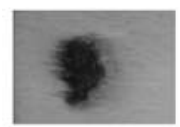

TPS - Day 05

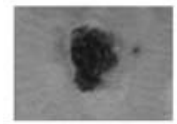

TPS - Day 07

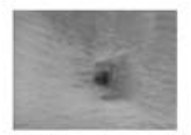

TPS - Day 10

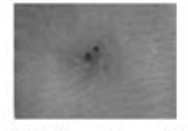

TPS - Day 15

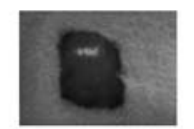

TBL - Day 00

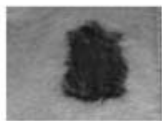

TBL - Day 01

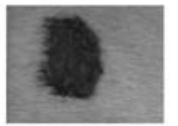

TBL - Day 02

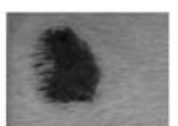

TBL - Day 03

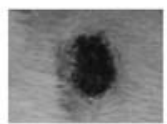

TBL - Day 05

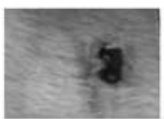

TBL - Day 07

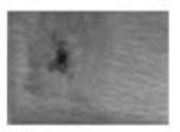

TBL - Day 10

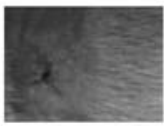

TBL - Day 15

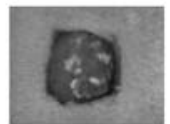

TSL - Day 00

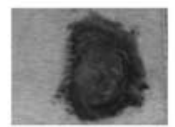

TSL - Day 01

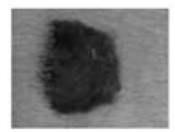

TSL - Day 02

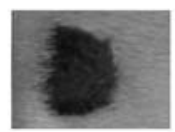

TSL - Day 03

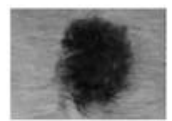

TSL - Day 05

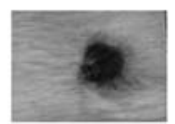

TSL - Day 07

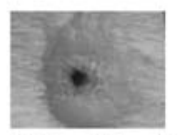

TSL - Day 10

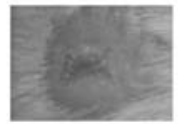

TSL - Day 15
FIGURE 4 - Macroscopic analysis of wound closure in rats treated with TPS, TBL, or TSL for 15 days. 

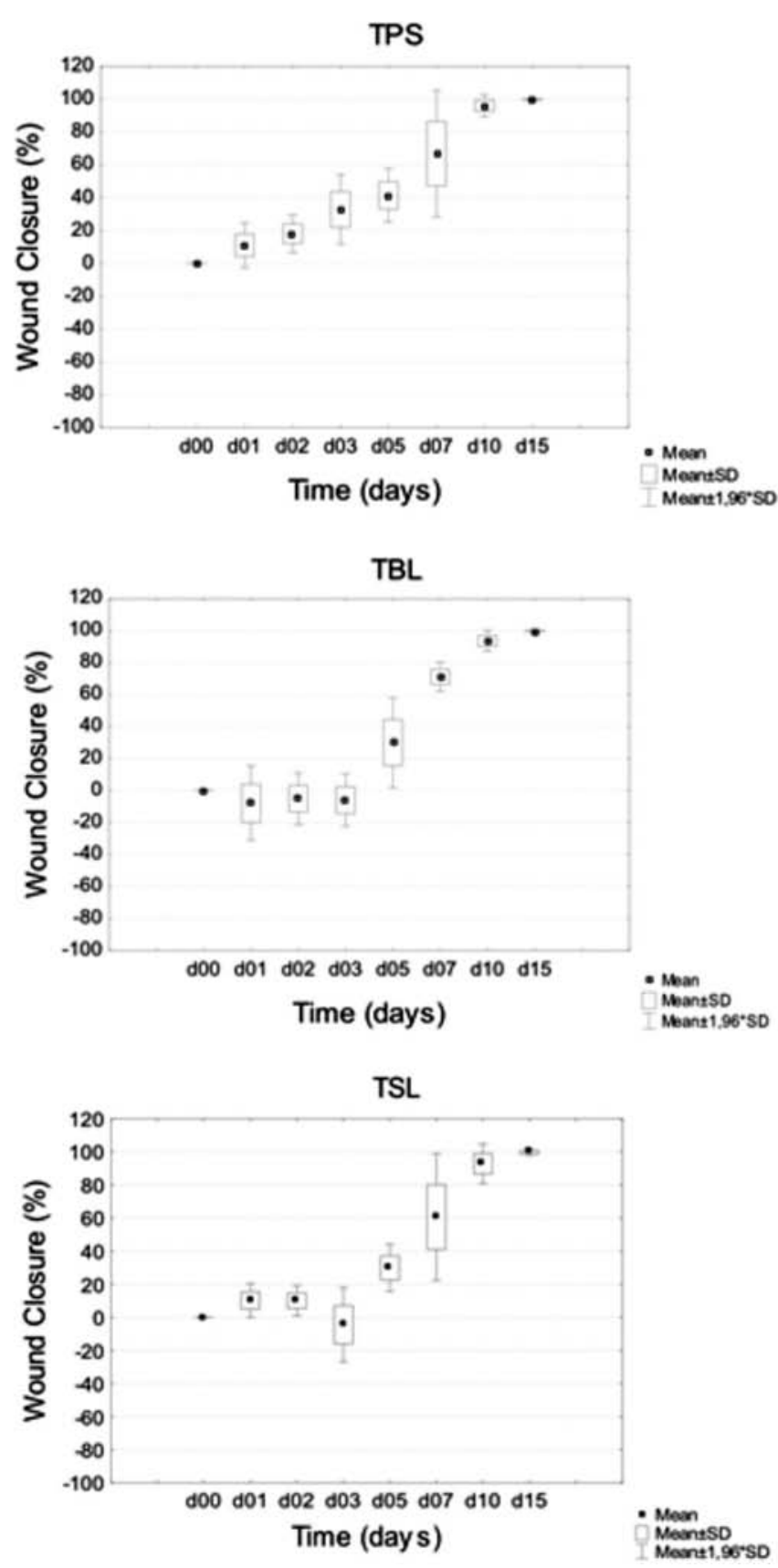

FIGURE 5 - Percentage reduction of wounds along the 15 days of treatment for TPS, TBL, and TSL.

with TBL and TSL had a steeper closure curve than the wounds treated with TPS. Irrespective of the occurrence of wound expansion before closure, all wounds completely closed in the course of 15 days. Although the treatment with the vegetable oil blends and structured lipids did not accelerate wound closure, the changes observed during the inflammatory phase suggest a potential therapeutic application in cutaneous wound healing which should be further investigated.

TBL and TSL did not differ in terms of wound closure at any point over the duration of the treatments. These results lead us to the conclusion that the changes in the regiospecific fatty acid redistribution promoted by enzymatic interesterification of BL1 and BL2 did not influence the wound closure process according to the macroscopic analysis.

In Figure 5, the high standard deviations observed reflect the large variations in the wound areas. These variations are due to the influence of a number of difficult-to-control factors such as the individual physical development of each animal, their circulation inside the cages, promoting undesirable contact between the animals and the cage cover or against each other.

Figure 6 shows the concentrations of the cytokines L-selectin, IL-6, and VEGF-a in homogenates of wounds over the course of 7 days and the integrated area of Figure 6(a).

Two days after wound induction, L-Selectin, IL-6, and VEGF-a reached their maximal concentrations in the control group (TPS), and likewise in the groups treated with the blends (TBL) and the structured lipids (TSL). In the control group, these concentrations started to decrease after two days, showing a tendency to return to their initial levels during the 7 days of the experiment. In the TBL group, a decrease in levels was observed after 5 days, but L-Selectin level increased and VEGF-a concentration returned to its maximum level after 7 days. No differences $(p<0.05)$ in cytokine concentrations were observed between the TPS and TSL groups at any time point in the ELISA analysis, which is confirmed by their integrated areas in Figure 6(b). However, TBL led to greater cytokine expression during the whole seven-day period, especially of IL-6, in relation to TPS and TSL groups.

The above-mentioned differences in the healing behavior of the wounds treated with lipids as compared to control treatment are probably due to immunomodulatory effects of specific fatty acids in the cells present in the healing process. Cardoso et al. (2004) analyzed wound closure after topical treatment of wounds with n-3, n-6, and n-9 unsaturated fatty acids. The results of their study indicated acceleration in the wound healing process in the first $48 \mathrm{~h}$ after surgery in rats treated with $\mathrm{n}-6$ fatty acids, as well as a tendency toward faster wound closure in the first 10 days of treatment in the group receiving n-9 fatty acids. The group also observed a tendency for delayed wound closure in the group treated with n-3 fatty acids. The modulating effects exerted by oleic and linoleic acids were noted by Pereira et al. (2008). In the cited study, oleic and linoleic acids were topically used to treat wounds of adult rats. Their results provided evidence that these fatty acids caused marked changes in the wounds 

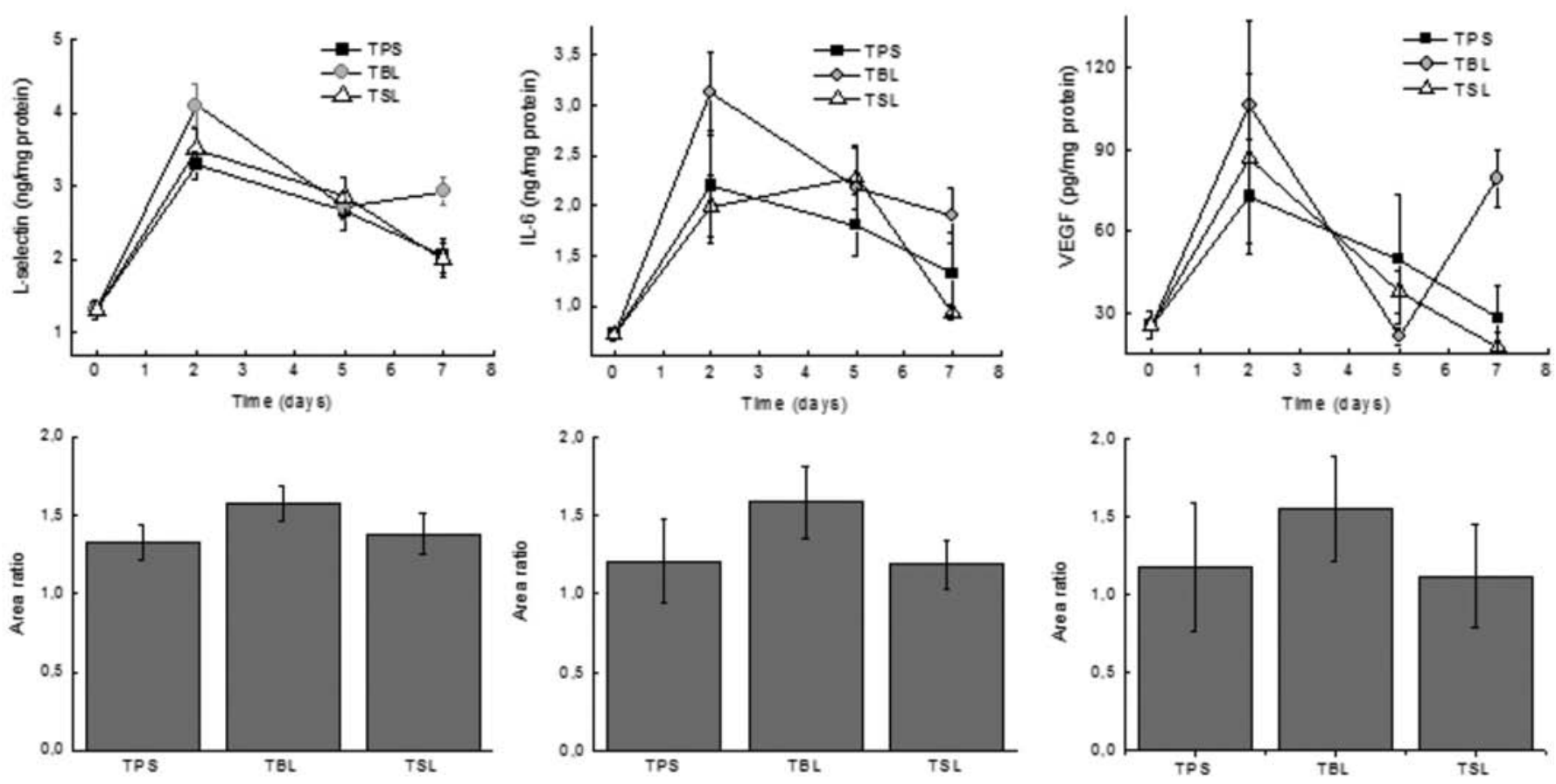

FIGURE 6 - Concentrations of L-selectin (ng/mg protein), IL-6 (ng/mg protein) and VEGF-a (pg/mg protein) in homogenates of wounds. (A) Wound cytokines concentration during the time course of 7 days and (B) The integrated area of Figure A.

during the inflammation period of the healing process. Both fatty acids led to an increase of approximately $32 \%$ in wet weight of the wound healing tissue mass $24 \mathrm{~h}$ after the surgery as compared to the control group. The authors attributed this increase to the effects of fatty acids on neutrophil migration and cytokine production in the injured area.

\section{CONCLUSIONS}

The production of new triacylglycerols through enzymatic interesterification was confirmed by the results obtained for triacylglycerol composition and fatty acid regiospecific distribution of the blends and their resulting structured lipids. However, the lipase did not present the expected specificity for the $s n-1,3$ positions as a result of acyl migration. No significant differences were observed between treatments with the blends and structured lipids. However, an increase in the areas of the wounds treated with lipids occurred in the inflammatory phase, probably as a result of the pro-inflammatory properties of the n-6 fatty acids present in BL1 and SL1. Subsequently, a steeper closure curve was observed, revealing an acceleration of the healing process. This was probably due to a combination of an initial exacerbation of the inflammatory stage with the anti-inflammatory effects of the $n-3$ fatty acids used in the tissue formation and tissue remodeling phases. Irrespective of the occurrence of wound expansion before closure, all wounds completely closed in the course of 15 days. Although the treatment with structured lipids did not accelerate wound closure, the changes observed during the inflammatory phase suggest a potential therapeutic application in cutaneous wound healing which should be further investigated.

\section{ACKNOWLEDGEMENTS}

The authors gratefully acknowledge the generous support from the Brazilian research funding agencies, Conselho Nacional de Desenvolvimento Científico e Tecnológico (CNPq), Coordenação de Aperfeiçoamento de Pessoal de Nível Superior (CAPES), and Fundação de Amparo à Pesquisa do Estado de São Paulo (FAPESP).

\section{REFERENCES}

ANTONIOSI-FILHO, n.; MENDES, O.L.; LANÇAS, F.M. Computer prediction of triacylglycerol composition of vegetable oils by HRGC. Chromatographia, v.40, n.9-10, p.557-562, 1995.

AMERICAN OIL CHEMISTS SOCIETY. AOCS. Official methods and recommended practices of the American Oil Chemists' Society. Champaign, 2004. Method Ce 1-62. 
BRADFORD, M.M. A rapid and sensitive method for the quantitation of microgram quantities of protein utilizing the principle of protein-dye binding. Anal. Biochem., v.72, n.1-2, p.248-254, 1976.

CARDOSO, C.R.B.; SOUZA, M.A.; FERRO, E.A.V. ; FAVORETO, S.; PENA, J.D.O. Influence of topical administration of $\mathrm{n}-3$ and $\mathrm{n}-6$ essential and $\mathrm{n}-9$ nonessential fatty acids on the healing of cutaneous wounds. Wound Repair Regen., v.12, n.2, p.235-243, 2004.

CHIU, M.C.; GIOIELLI, L.A.; GRIMALDI, R. Lipídios estruturados obtidos a partir da mistura de gordura de frango, sua estearina e triacilgliceróis de cadeia média. II - Pontos de amolecimento e fusão. Quim. Nova, v.31, n.2, p.238-243, 2008.

CODEX ALIMENTARIUS. Codex Standard for Named Vegetable Oils. Available at: <http://www. codexalimentarius.net/web/standard_list.do?lang=en $>$. Accessed on: 10 dec. 2011.

COSTALES-RODRIGUEZ, R.; GIBON, v.; VERHE, R.; DE GREYT, W. Chemical and enzymatic interesterification of a blend of palm stearin: soybean oil for low trans-margarine formulation. J. Am. Oil Chem. Soc., v.86, n.7, p.681-697, 2009.

FIRESTONE, D. Physical and chemical characteristics of oils, fats, and waxes. 2. ed. Champaign: AOCS Press, 2006. $237 \mathrm{p}$.

GILLITZER, R.; GOEBELER, M. Chemokines in cutaneous wound healing. J. Leukocyte Biol., v.69, n.4, p.513-521, 2001.

GUNSTONE, F.D.; HARWOOD, J.L. Occurrence and characterization of oils and fats. In: GUNSTONE, F.D; HARWOOD, J.L.; DIJKSTRA, A.J. The lipid handbook. 3. ed. Boca Raton: CRC Press, 2007. chap.2, p.37-141.

GUNSTONE, F.D.; HERSLÖF, B.G. Lipid Glossary 2. Bridgwater: PJ Barnes \& Associates, 2000. Available at: $<$ http://www.dr-baumann-international.co.uk/science/Ebook\%20Lipid\%20Glossary.pdf $>$. Accessed on: 05 jan. 2015 .

HARTMAN, L.; LAGO, R.C.A. Rapid preparation of fatty acid methyl esters from lipids. Lab. Pract., v.22, n.6, p.475-494, 1973.
HUNTER, J.E. Studies on effects of dietary fatty acids as related to their position on triglycerides. Lipids, v.36, n.7, p.655668, 2001.

KARUPAIAH, T.; SUNDRAM, K. Effects of stereospecific positioning of fatty acids in triacylglycerol structures in native and randomized fats: a review of their nutritional implications. Nutr. Metab., v.4, n.16, p.1-17, 2007.

KIM, B.H.; AKOH, C.C. Characteristics of structured lipid prepared by lipase-catalyzed acidolysis of roasted sesame oil and caprylic acid in a bench-scale continuous packed bed reactor. J. Agric. Food Chem., v.54, n.14, p.5132-5141, 2006.

LEE, K.T.; AKOH, C.C. Structured lipids: synthesis and applications. Food Rev. Int., v.14, n.1, p.17-34, 1998.

MCDANIEL, J.C.; BELURY, M.; AHIJEVYCH, K.; BLAKELY, W. Omega-3 fatty acids effect on wound healing. Wound Repair Regen, v.16, n.3, p.337-345, 2008.

MU, H.L.; PORSGAARD, T. The metabolism of structured triacylglycerols. Prog. Lipid Res., v.44, n.6, p.430-448, 2005.

NEVIN, K.G.; RAJAMOHAN, T. Effect of topical application of virgin coconut oil on skin components and antioxidant status during dermal wound healing in young rats. Skin Pharmacol. Phys., v.23, n.6, p.290-297, 2010.

OH, J.E.; LEE, K.W.; PARK, H.K.; KIM, J.Y.; KWON, K.I.; KIM, J.W.; KIM, H.R.; KIM, I.H. Lipase-catalyzed acidolysis of olive oil with capric acid: Effect of water activity on incorporation and acyl migration. J. Agric. Food Chem., v.57, n.19, p.9280-9283, 2009.

OTRANTO, M.; NASCIMENTO, A.P. ; MONTE-ALTOCOSTA, A. Effects of supplementation with different edible oils on cutaneous wound healing. Wound Repair Regen, v.18, n.6, p.629-636, 2010.

PARK, J.E.; BARBUL, A. Understanding the role of immune regulation in wound healing. Am. J. Surg., v.187, n.5A, p.11S-16S, 2004.

PEREIRA, L.M.; HATANAKA, E. MARTINS, E.F.; OLIVEIRA, F.; LIBERTI, E.A.; FARSKY, S.H.; CURI, R.; PITHON-CURI, T.C. Effect of oleic and linoleic acids on the inflammatory phase of wound healing in rats. Cell Biochem Func, v.26, n.2, p.197-204, 2008. 
REENA, M. B.; LOKESH, B. R. Hypolipidemic effect of oils with balanced amounts of fatty acids obtained by blending and interesterification of coconut oil with rice bran oil or sesame oil. J. Agr. Food Chem., v.55, n.25, p.10461-10469, 2007.

RODRIGUES, H.G.; VINOLO, M.A.R.; MAGDALON, J.; FUJIWARA, H.; CAVALCANTI, D.M.H.; FARSKY, S.H.P.; CALDER, p.C.; HATANAKA, E.; CURI, R. Dietary free oleic and linoleic acid enhances neutrophil function and modulates the inflammatory response in rats. Lipids, v.45, n.9, p.809-819, 2010.

RODRIGUES, H.G.; VINOLO, M.A.R.; MAGDALON, J.; VITZEL, K.; NACHBAR, R. T.; PESSOA, A. F. M.; SANTOS, M.F.; HATANAKA, E.; CALDER, p.C.; CURI, R. Oral administration of oleic or linoleic acid accelerates the inflammatory phase of wound healing. J. Invest. Dermatol., v.132, n.1, p.208-215, 2011.

SEN, C.K.; GORDILLO, G.M.; ROY, S.; KIRSNER, R.; LAMBERT, L.; HUNT, T.K.; GOTTRUP, F.; GURTNER, G.C.; LONGAKER, M.T. Human skin wounds: A major and snowballing threat to public health and the economy. Wound Repair Regen. v. 17, n.6, p.763-771, 2009.

SILVA, R.C.; RIBEIRO, A.P. B.; MARTINI SOARES, F.A.S.; CAPACLA, I.R.; HAZZAN, M.; SANTOS, A.O.; CARDOSO, L.P. ; GIOIELLI, L.A. Microstructure and thermal profile of structured lipids produced by continuous enzymatic interesterification. J. Am. Oil Chem. Soc., v.90, n.5, p.631-639, 2013.

SOARES, F.A.S.D.M.; SILVA, R.C.; SILVA, K.C.G.; LOURENÇO, M.B.; SOARES, D.F.; GIOIELLI, L.A. Effects of chemical interesterification on physicochemical properties of blends of palm stearin and palm olein. Food Res. Int., v.42, n.9, p.1287-1294, 2009.

STANDAL, I.B.; AXELSON, D.E.; AURSAND, M. Differentiation of fish oils according to species by ${ }^{13} \mathrm{C}-\mathrm{NMR}$ regiospecific analyses of triacylglycerols. J. Am. Oil Chem. Soc., v.86, n.5, p.401-407, 2009.
VLAHOV, G. C-13 NMR spectroscopy to determine structure and composition of waxes and glycerides. Curr. Pharm. Anal., v.4, n.3, p.126-136, 2008.

WANG, J.; SUÁREZ, E.R.; KRALOVEC, J.; SHAHIDI, F. Effect of chemical randomization on position distribution and stability of omega-3 oil triacylglycerols. J. Agric. Food Chem., v.58, n.15, p.8842-8847, 2010.

WHITE, p.J. Fatty acids in oilseeds (vegetable oils). In: CHOW, C. K. Fatty acids in foods and their health implications. 3. ed. Boca Raton: CRC Press, 2008. chap.10, p.227-262.

WILLIS, W.M.; MARANGONI, A.G. Enzymatic Interesterification. In: AKOH, C. C.; MIN, D. B. (Eds.). Food lipids: chemistry, nutrition, and biotechnology. 3. ed. Boca Raton CRC Press, 2008. chap.30, p.807-840.

XU, X. Enzymatic production of structured lipids: process reactions and acyl migration. INFORM, v.11, p.1121-1131, $2000 a$.

XU, X. Production of specific-structured triacylglycerols by lipase catalyzed reactions: a review. Eur. J. Lipid Sci. Technol., v.102, p.287-303, 2000 b.

YANG, T.; XU, X.; LI, L. Comparison of linoleic and conjugated linoleic acids in enzymatic acidolysis of tristearin. J. Food Lipids, v.8, n.3,p. 149-161, 2001.

YANG, T.K.; FRUEKILDE, M.B.; XU, X.B. Suppression of acyl migration in enzymatic production of structured lipids through temperature programming. Food Chem., v.92, n.1, p.101-107, 2005.

Received for publication on $06^{\text {th }}$ May 2014 Accepted for publication on $23^{\text {rd }}$ February 2015 
